Maurice A. Deane School of Law at Hofstra University Scholarly Commons at Hofstra Law

Hofstra Law Faculty Scholarship

$10-2006$

\title{
Foreword to the Special Issue on the Family Law Education Reform Project
}

Andrew Schepard

Maurice A. Deane School of Law at Hofstra University

Peter Salem

Follow this and additional works at: https://scholarlycommons.law.hofstra.edu/faculty_scholarship Part of the Family Law Commons

\section{Recommended Citation}

Andrew Schepard and Peter Salem, Foreword to the Special Issue on the Family Law Education Reform Project, 44 Fam. Ct. Rev. 513 (2006)

Available at: https://scholarlycommons.law.hofstra.edu/faculty_scholarship/499

This Article is brought to you for free and open access by Scholarly Commons at Hofstra Law. It has been accepted for inclusion in Hofstra Law Faculty Scholarship by an authorized administrator of Scholarly Commons at Hofstra Law. For more information, please contact lawcls@hofstra.edu. 


\title{
SPECIAL ISSUE: THE FAMILY LAW EDUCATION REFORM PROJECT
}

\section{FOREWORD TO THE SPECIAL ISSUE ON THE FAMILY LAW EDUCATION REFORM PROJECT}

\author{
Andrew Schepard \\ Peter Salem
}

The purpose of this issue is to promote a dialogue between the family law academic community and stakeholders in the family law system about how future family lawyers should be educated. Family law practice has undergone dramatic change in the last quarter century, perhaps more than any other area of practice. Virtually everything about it has changed - the role of the family court, the procedure for resolving family disputes, the role of the family lawyer, and the substantive law. It is a vibrant and exciting field, with great influence on the lives of families and children.

The family law curriculum in our law schools, however, does not reflect either the change in practice or its vibrancy. Despite the enormous challenges of modern practice, and the high stakes for parents and children, family law remains the stepchild of the law school. There are efforts to modernize underway, but they are isolated and unsystematic.

\section{THE FAMILY LAW EDUCATION REFORM PROJECT}

The Family Law Education Reform Project (FLER) was created to systematically address the gap between the teaching and practice of family law. FLER is a unique undertaking in legal education - the first critical interdisciplinary outside look at the family law curriculum. FLER is a collaboration between a law school (Hofstra Law School's Center for Children, Families and the Law) and the Association of Family and Conciliation Courts (AFCC), an interdisciplinary organization of family court professionals that has been a leader in developing family dispute resolution processes and is outside of the academy.

Beginning with an open forum at AFCC's 2004 Annual Conference in San Antonio, FLER has systematically solicited the opinions of hundreds of law professors, judges, lawyers, mental health professionals, custody evaluators, mediators, researchers, law students, and others in order to better understand how to train family lawyers who can better meet the needs of the families and communities they serve. The process has included "think tanks" of invited family law faculty and interdisciplinary professionals, an Internet survey of eight family law and related professional associations, research

Correspondences: Andrew Schepard: Andrew.I.Schepard@hofstra.edu

Peter Salem: psalem@afccnet.org

FAMILY COURT REVIEW, Vol. 44 No. 4, October 2006 513-521

(C) 2006 Association of Family and Conciliation Courts 
conducted by students at Hofstra Law School, and presentations and feedback sessions at conferences sponsored by AFCC, the American Association of Law Schools, the National Council of Juvenile and Family Court Judges, the American Bar Association (ABA) Section of Dispute Resolution, and the Association for Conflict Resolution Family Section.

\section{WHAT'S CONTAINED IN THIS ISSUE}

The centerpiece of this issue is the Family Law Education Reform Project Report (hereinafter Report or FLER Report) on the state of family law education written by its Reporters, Professors J. Herbie DiFonzo of Hofstra University Law School and Mary E. O'Connell of Northeastern University School of Law. The Report examines the relevance of today's family law curriculum to the rapidly changing world of family law practice. It documents a significant gap between education and practice that calls into question the quality of representation that future family lawyers will provide. The Report calls for a reexamination of the law school's family law curriculum to incorporate alternatives to litigation, interdisciplinary knowledge, and essential lawyering skills, all of which are not adequately covered in most law school family law curricula today.

\section{ENDORSEMENTS}

The FLER Report has touched a nerve with stakeholders in the family law system, demonstrated by the list of major organizations that endorse the initial draft, including:

- National Council of Juvenile and Family Court Judges,

- ABA Section of Dispute Resolution,

- National Association of Counsel for Children,

- Association for Conflict Resolution, and

- International Academy of Collaborative Professionals (collaborative lawyers).

Many distinguished individuals from many disciplines also endorse the Report and are a tribute to its importance.

In addition, the Supreme Court of Ohio has appointed a subcommittee of its Family Law Commission to examine the implementation of the FLER recommendations in Ohio. The planning committee for the ABA Youth at Risk Initiative has recommended consideration of the Report and that the ABA assist with its implementation to ensure that law schools better address critical issues related to youth.

Anecdotally, the response to the FLER Report has been extraordinarily supportive and the enthusiasm with which our colleagues have embraced this project strongly suggests that the time is right for family law education reform.

\section{COMMENTARIES}

To further stimulate readers' thinking about the nature and future of family law legal education, this issue also includes commentary on the FLER Report by:

- Nicholas Bala, a family law professor and former associate law school dean at Queens University in Canada, who discusses the feasibility of implementing FLER's recommendations in the current world of legal academia; 
- Catherine J. Ross, a family law professor at George Washington Law School, who describes what a family law case book revised to incorporate FLER's recommendations might look like;

- Jennifer Rosato, a family law professor at Brooklyn Law School, who describes the problems of incorporating alternative dispute resolution into a traditional law school course and how those barriers can be overcome with imagination and energy;

- Marsha Kline Pruett, a Yale University-based psychologist and distinguished researcher of the legal system, divorce, and children, who describes why the recommendations of FLER are critical for clients of future lawyers;

- Alexis Collentine, a third-year law student and Child and Family Advocacy Fellow at Hofstra Law School, who describes the impact of FLER's recommendations on her education.

\begin{abstract}
ADDITIONAL ARTICLES
Next, this issue contains two longer articles that provide additional empirical support for FLER's recommendations. Timothy Hedeen, a professor at Kennesaw State University, and Peter Salem, FLER Co-chair and AFCC Executive Director, describe their survey for FLER of family court professionals and law students of the skills, knowledge, and attributes necessary for effective family law practice in the modern era. They report that survey respondents emphasized the importance of strong interpersonal skills like listening, negotiating, and working with clients in emotional crisis, as well as understanding of financial issues in family law, the impact of divorce and separation on children, and the ethical dimension of family law practice. The FLER Report documents how these skills and knowledge areas get little attention in most family law curricula.

Andrea Schneider, a law professor at Marquette Law School and a well-known expert in negotiation philosophy and tactics, and Nancy Mills, a 2005 graduate of Marquette and a mediator and family law attorney, describe the results of their survey of the negotiation effectiveness of the bar. Their study included a survey of the effectiveness of the divorce bar in a major city. They report that family lawyers are more adversarial and less effective in their negotiations than most other specialty bars they surveyed and discuss the implications of their findings.
\end{abstract}

\title{
STUDENT NOTES
}

Two Hofstra Law students further elaborate on the themes and questions raised by the FLER Report:

- Dori Cohen argues that alternative dispute resolution should be a mandatory topic for both bar examinations and continuing education for lawyers.

- Donna Tumminio surveys practices in many states and argues that courts should routinely appoint neutral experts in divorce actions to appraise the value of a business that is a marital asset.

\section{OUR PERSPECTIVES ON FLER AND FAMILY LAW EDUCATION}

We are energized by the reexamination of the assumptions of family law education that FLER has inspired and believe that the material in this issue will give readers essential background to participate in it. We hope that readers will indulge a short contribution from the two of us on that subject. 


\section{THE GROWTH OF COLLABORATIVE DISPUTE RESOLUTION FOR FAMILIES}

We begin with our own perspective on the need for change in family law education, an elaboration of some of the changes documented in the FLER Report. In our view, in the last quarter century, the process of resolving legal family disputes has, both literally and metaphorically, moved from confrontation toward collaboration and from the courtroom to the conference room. Resolving legal family conflict under the classic adversarial model is often a lawyer-centered and rights-based activity. Settlement negotiations are typically distributive, consisting of a series of telephone calls between lawyers, with each periodically contacting his or her client to provide information and advice. The process encourages parties and their lawyers to think of themselves as adversaries - a gain for one is a loss for the other-and resist making concessions. Failing a negotiated settlement, a judge adjudicates disputed legal or factual issues between members of a family (or between family members and the state) based on statutes, precedent, and evidence presented by counsel for the parties.

The collaborative model of family law dispute resolution takes an interest-based approach and is more likely to include active participation by the clients themselves, for example, as participants in a divorce education program, a four-party settlement conference, or in mediation. While lawyers serve as advocates, a greater emphasis is placed on (1) the role of the legal counselor and advisor, (2) working to identify a resolution that meets the needs of all family members, and (3) interpersonal or emotional issues that frequently underlie the legal dispute. As in the adversarial model, the last resort remains a judicial decision based on the legal issues in dispute.

The adversarial and collaborative models may not be as clearly differentiated in actual practice, which may blend the two together, as in theory. But the classic adversarial model faces significant challenges functioning effectively in today's family court for the great majority of cases. Today's family court docket consists of an avalanche of cases and available data that indicates that the majority of litigants are pro se (self-represented). The adversarial model is also under scrutiny because litigation frequently increases the bitterness and long-lasting harm to relationships between family members and children rather than addressing their needs and continuing relationships. Finally, many have criticized the adversarial model for the added expense and delay it requires in the resolution of family disputes.

In many jurisdictions, today's family court judge is more than an adjudicator. In addition, he or she may oversee a multidisciplinary group of service providers all engaged with the children and families whose cases are before the court. Many jurisdictions have created unified family courts that group a range of issues - from divorce and custody to juvenile crime to child support - under one courthouse roof, with a single judge deciding all legal issues relating to a single family. Many jurisdictions have created specialized courts for domestic violence, drug abuse, and permanency planning; these courts compel litigants to participate in both mental health and social services designed to serve therapeutic and rehabilitative goals.

Some jurisdictions have created multidoor family courthouses. Today's family courts incorporate and frequently mandate a wide variety of dispute resolution options (e.g., mediation, family group conferencing, educational programs, parenting coordinators, early neutral evaluation for parenting and financial maters, arbitration) to resolve disputes without adjudication. When disputes are adjudicated, family courts increasingly rely on neutral expert reports from professionals in disciplines (e.g., mental health experts, financial 
appraisers) appointed by the court rather than hired by a party. Negotiated settlements reflect the influence of these expert reports and are thus more informed.

\section{THE CHANGING ROLE OF THE FAMILY LAWYER}

The role of the family lawyer is also evolving to keep pace with changes in the family law system. Many argue that family lawyers should have different ethical responsibilities than lawyers in traditional civil and criminal cases, including a responsibility to discuss alternative dispute resolution with their clients and an obligation to "do no harm" to their clients' children. Today's family lawyer certainly must be fully equipped to provide legal advice. He or she, however, must also be equipped to work with professionals from different disciplines and multiple dispute resolution processes in an increasingly complex and differentiated system. The traditional full-service adversarial model of lawyer representation is increasingly being challenged by emerging models that call for problem solving, collaboration, and unbundled (limited task) representation.

In addition to a traditional adversarial system-based full-service counselor and litigator, today's family lawyer may function as:

- Counselor dealing with an emotionally stressed client

- Financial or tax advisor planning for a postdivorce future

- Collaborative negotiator who seeks interest-based, problem-solving solutions for disputed issues

- Mediator

- Representative of a party in mediation (mediation advocate)

- Provider of unbundled legal services (limited task representation) providing discrete legal advice to a client on a particular topic

- Member of a collaborative law practice group

- Child's lawyer

- Parenting coordinator

- A member of a parent education team

- Courtroom advocate dealing with expert testimony of court-appointed mental health and financial experts

- Judge, magistrate, or referee in a unified family court or a specialized problem-solving court, focusing on permanency planning or domestic violence, or in a traditional courtroom

\section{INCREASINGLY COMPLEX SUBSTANTIVE LAW}

Concurrently, social, political, and intellectual developments of the last quarter century have transformed and complicated family law. A listing of just some of the recent developments makes the point: covenant marriage; no-fault divorce; making inchoate property (stock options, pensions, intellectual property rights, partnership arrangements) divisible at divorce; recognition of marital and premartial contracts; financial and parenting rights for cohabitants; statutory formulas for child support; joint custody and parenting plans; third-party and grandparent visitation rights; same-sex marriage and recognition of alternative family forms; greater emphasis on domestic violence and child abuse and neglect; surrogate parenting; an effort to reduce time in foster care and increase the speed of adoption; and international treaties seeking to reduce child abduction and recognize the rights of children. 


\section{OUR RECOMMENDATIONS FOR FAMILY LAW EDUCATION REFORM}

The recommendations of the FLER Report are primarily directed to law professors as individuals and suggest curricular enhancement opportunities they might want to undertake in their courses. The recommendations we make in this Foreword go further and are addressed to law school deans and faculties who have the responsibility for making curricular and resource allocation decisions for the law school as a whole. Some of our recommendations are also addressed to officials who regulate the bar and make up the bar examination.

Our recommendations are also addressed to the family law and court stakeholders outside of academia - judges, lawyers, mediators, mental health professionals, social service professionals, and financial experts. We ask those practitioners to approach their local law school about how they can help. The law school family law curriculum needs to creatively engage them in the training and education of the future family law practitioner. In return, they should give generously of their time and expertise in training future family lawyers.

\section{CURRICULAR REFORM}

Law schools should reevaluate their family law curriculum to include subjects such as:

- Goals and objectives of family dispute resolution (i.e., the tension between rights, needs, and interests of parents, children, and families)

- The appropriate role of the family court and the family court judge

- The multiple roles and ethical responsibilities of the family lawyer (children's lawyer, best interests lawyer, courtroom advocate, mediator, mediation advocate, legal counselor, unbundled advisor, collaborative lawyer, and parent coordinator)

- Role of allied professionals (mental health experts and financial professionals) in family dispute resolution

- Dispute resolution processes

- Unrepresented litigants

- Family violence

In addition, the law school curriculum should make available opportunities for skill development for those students who wish to practice family law through a combination of course work and experiential methods including instruction in:

- Interpersonal skills, including interviewing and counseling (active listening), especially with clients in emotional distress

- Negotiation

- Mediation representation

- Advocacy, working with court-appointed mental health and financial experts, both in the negotiation room and the courtroom

- Law office management

- Screening for domestic violence

- Screening for child abuse and neglect

\section{FAMILY LAW AS A REQUIRED COURSE}

Given the importance of families and family law to society and the legal system, we suggest that law schools consider making a basic family law course required for all law students. 
We recognize that the trend in most law schools is to reduce, not increase, the number of required courses. We do not understand, however, how a future lawyer (and citizen and community leader) can graduate from law school without basic knowledge about how the legal system deals with the most fundamental institution in society - the family. We are concerned about reports received during FLER's consultations, indicating that, in those states where family law is not on the bar examination, law student enrollment tends to drop substantially.

\section{THE BAR EXAMINATION}

A state's bar examination sets the basic framework for what its law schools must teach. Family law and dispute resolution are vital subjects, more important than almost any other to the citizens of a state. Serious consideration should thus be given to including family law and alternative dispute resolution, especially as it is practiced in family cases, on the bar examination. When the bar examination talks, law schools tend to listen.

\section{ADVANCED TRAINING AND CONTINUING EDUCATION}

On the other end of the curricular spectrum, the increasing challenges of modern family law representation suggest that law schools should offer many elective courses beyond the basic family law course. They should also consider certificate programs, concentrations, and advanced degree programs for those wishing to specialize in family law.

In addition, regulators who approve continuing education courses should feature family law and family dispute resolution procedure prominently in their offerings.

\section{INVOLVING STAKEHOLDERS IN THE FAMILY LAW CURRICULUM}

Family law professionals - judges, lawyers, mediators, parent educators, mental health experts, financial planners - can become actively involved in the family law curriculum by participating in projects such as:

- Serving on a law school interdisciplinary family law advisory committee

- Guest lecturing and adjunct teaching

- Mentoring

- Providing opportunities for law students to observe court proceedings, negotiations, and mediations

- Opening memberships in professional associations to law students

- Supervising pro bono opportunities such as help centers, and intake

- Providing job counseling and advice

Family courts, where proceedings are often confidential and closed, should especially make efforts to ensure that future lawyers understand their mission and operations. They should open their doors to law schools through externship programs and fieldwork observations, allowing students opportunities to participate in their processes to the maximum extent feasible.

\section{WHERE DO WE GO FROM HERE?}

We hope that the FLER Report will continue to spark active consideration of how to make family law a wanted and energetic member of the law school curricular family that 
will train future practitioners for the challenges ahead. We also hope that it will spark a strong collaboration between law schools and the professionals who work in the family court-judges, lawyers, mediators, mental health and financial professionals - that will make the training of future professionals relevant, alive, and vibrant, to attract the best and the brightest to family law practice.

The FLER Project's next steps will be to develop curricular modules on key topics such as child development, domestic violence, alternative dispute resolution, and pro se litigants, that can be made easily available to those teaching family law. In addition, we are looking to cosponsor a series of stakeholders meetings to bring together representatives of law schools, the bench, bar, mental health, and dispute resolution communities to discuss implementation issues.

\section{ACKNOWLEDGMENTS}

The FLER Project is the result of collective efforts of dozens of dedicated professionals. Professors O'Connell and DiFonzo, FLER's reporters, particularly deserve our gratitude. Their task was formidable: to write a report that merged the observations of dozens of professionals from many disciplines and that could be used as a catalyst for reforming family law education. The reporters used the expertise and keen insights of the participants to create a document that will help law professors understand how to make the journey from current law teaching to a more effective family and child-centered approach to educating future family lawyers.

We also want to thank Dean Aaron Twerski and Vice Dean Marshall Tracht of Hofstra Law School for their ongoing support of this project. The AFCC Board of Directors has supported this project since its inception and former AFCC Presidents Leslye Hunter and Hon. Hugh Starnes and Board Member Bill Howe served on the FLER Project Steering Committee. Additional Steering Committee members include Professors John Lande and Jennifer Rosato, and Dr. Gregory Lampe, Associate Vice Chancellor for Academic Affairs at the University of Wisconsin Colleges, who provided (and continues to provide) invaluable guidance as our curriculum consultant. We also thank Timothy Hedeen, our research consultant, and Tom Fee, project facilitator, who insured a collaborative and productive process throughout.

We thank all of the project participants who were so generous with their time, energy, and ideas. The combined efforts of these individuals have created an ambitious agenda for change that will benefit future family lawyers, law schools, courts, and above all, parents and children. This project would not have been possible without support from the JAMS Foundation and its Executive Director, Professor Jay Folberg, and the Johnson Foundation and its Program Officer, Chris Beem.

Last, but by no means least, a heartfelt thanks to the law students of Hofstra Law School and Northeastern Law School for their contribution to this project. They are: Heather Abissi, Sharon Clarke, Alexis Collentine, Danielle Passano, and Marion Perry from Hofstra and Sarah Brady Lay and Daniel Miller from Northeastern. This project is for them and others who will follow in their footsteps.

\footnotetext{
Andrew Schepard is Professor of Law, Hofstra University School of Law and the Director of Hofstra University's interdisciplinary Center for Children, Families and the Law. He is the editor of Family Court Review and the author of Children, Courts and Custody: Interdisciplinary Models for Divorcing Families (Cambridge University Press, 2004). Professor Schepard was the Reporter for the Model Standards of Practice for Family and Divorce Mediation approved by the American Bar Association, the Association of Family and Conciliation Courts, and the Association for Conflict Resolution and the Reporter for the
} 
American Bar Association's Leadership Summit on Unified Family Courts. He has received numerous awards from the American Bar Association and the Association of Family and Conciliation Courts for his work with families and children in conflict. Professor Schepard is a graduate of Harvard Law School, where he served as Articles Editor of the Harvard Law Review. He also served as a Law Clerk to former Chief Judge James L. Oakes of the U.S. Court of Appeals for the Second Circuit. Professor Schepard is an elected member of the American Law Institute and a Fellow of the American Bar Foundation.

Peter Salem is executive director of the Association of Family and Conciliation Courts and co-chair of the Family Law Education Reform Project. He is an adjunct professor of law at Marquette University, where he teaches mediation and is co-editor of the book Divorce and Family Mediation: Models, Techniques and Applications. He served as director and mediator of Mediation and Family Court Services in Rock County, Wisconsin, and has provided training and technical assistance to court services throughout the United States. 